\title{
RESEARCH SKILLS OF STUDENTS DURING THE LESSONS OF NATURAL AND MATHEMATICAL DISCIPLINES: THE OBJECT OF HISTORICAL AND PEDAGOGICAL STUDY (1959-1972 OF THE XXth CENTURY)
}

\author{
Natalia Halytska \\ Postgraduate Student, Kherson Academy of Continuing Education, Ukraine \\ e-mail: a19natalia77evgenia@gmail.com, orcid.org/0000-0001-7097-3180
}

\begin{abstract}
Summary
Research skills are considered as an object of historical and pedagogical research. The historical limits for the formation of research skills in the lessons of mathematics, physics, chemistry, geography, biology are determined. The challenges that preceded the skills and the consequences that led to their formation are pointed out. The borders correspond to the legal documents of public education in Soviet Union.

The main criteria that determined the development of public education in general, and secondary education in particular, were the congresses of the Central Committee of the CPSU, resolutions of the Ministry of Education, the All-Union Congress of Teachers. The gradual formation of the very definition in the historical aspect of educational reforms during the Soviet education is considered. The transformation of the concept of "research skills" is characterized: botanical skills - polytechnic skills - polytechnic in combination with intellectual skills.

In the period outlined by us, we observe the greatest development of the concept occurred in the mid-60's. Examples of formation of research skills during the lessons of natural and mathematical disciplines are given.
\end{abstract}

Keywords: lesson; skills; research skills; Soviet education; polytechnic education.

\section{DOI: https://doi.org/10.23856/3818}

\section{Introduction}

The education system of Ukraine is at the stage of formation according to modern integration processes, the vectors of which are aimed at European and international educational landmarks. Gradually, changes are being made in accordance with the state national program "Education" ("Ukraine of the XXI century"). In accordance with democratic values, achievements of modern science and technology, the priority for all members of society is the availability of quality education throughout life.

In Ukraine, profound changes are taking place to improve the quality and competitiveness of education in the new economic, political and socio-cultural conditions. The state document "National Strategy for Educational Development in Ukraine for 2012-2021" addresses the problems of forming a modern worldview, development of creative abilities, skills of independent scientific knowledge, self-education and self-realization of the modern personality.

The issue of forming competencies in students and youth is relevant. Education reform in the Ukrainian state requires changes in the secondary level of education, where in the near future there will be requirements for the formation of research competencies.

Choosing the right priority will help to study the history of this issue. In our opinion, considering the gradual formation of research skills in the history of pedagogy will help to avoid mistakes in the future and improve modern heritage. 
A novelty is the gradual synergetic transformation of research skills in lessons of natural and mathematical disciplines, based on the analysis of archival sources.

The aim of the article is to characterize each historical stage of our study during the Soviet education.

The methodology research accumulates a gradual acquisition not only of research skills as such, but also of various influences (conditions, challenges, means, etc.), which led to the emergence of transformed skills into research competence.

\section{The period from 1959 to 1965 of the XX century}

The periods we have singled out aim at the main aspects for the development and formation of research skills. They were preceded by political, social and economic challenges. The end of the 1950s was characterized by the adoption of the law "On strengthening the connection between school and life and on the further development of the public education system in the USSR" (April 17, 1959). Prerequisites are: historical decisions of the XXI Congress of the Central Committee of the CPSU (27.01-05.02.1959), which noted the connection of training with industrial labor; decision of the December Plenum of the Central Committee of the CPSU to increase the production of agricultural products. The main issues worked on by the departments of public education and schools at the beginning of this period were the strengthening of the educational and material base of the office, the coverage of all school-age children, the combination of teaching basic sciences with industrial training and socially useful work. Public education has chosen as a priority the close connection of teaching the basics of science with life.

Restructuring the system of public education and conducting various methodological activities provided an opportunity to improve the quality of lessons. For example, a teacher of mathematics at a secondary school in Luhansk, who systematically linked the teaching of mathematics with other subjects, successfully organized independent work closely related to production. "... In one of the lessons the teacher together with the teacher of drawing, agreed that in his lesson he would consider finding the cross section of the prism. Due to the fact that the students understood well what geometric figure is obtained by cross-section, the task was to solve without difficulty" (Richnyi zvit pro robotu shkil Luhanskoi oblasti za 1958-1959 n.r., 1959: 24).

According to the order of the Ministry of Education dated March 18, 1958. "On the state of teaching physics in secondary and seven-year schools of the USSR" also improved physics teaching. The focus was on the organization of laboratory work, on replenishing the training facilities of the office, on improving practical knowledge and skills. Thus, the Chernihiv region in 1958-1959 academic year. (secondary school № 1 N-Siverska, secondary school № 4 Nizhyn, secondary school № 8 Chernihiv) was marked by the improvement of practical knowledge and skills. For example, "VI grade students were able to use a scale ruler, beaker, scales, barometer. Pupils of VII class were able to measure temperature, to deal with galvanic cells and accumulators, to make electric circuits. Most students in grades VIII-X used measuring instruments and instruments and accompanied their answers with demonstrations of relevant experiments" (Richnyi zvit pro robotu shkil Chernihivskoi oblasti za 1958-1959 n.r., 1959: 46).

Given the technical progress of the country and the chemicalization of the national economy, for example, teachers of Poltava region (Poltava secondary school № 6, Kremenchug secondary school № 4, Svyatylivka secondary school of Hradiz district) "paid great attention to studying the basics of chemical production, properties of substances and their application in 
various fields national economy, instilled in students' practical skills and abilities" (Richnyi zvit pro robotu shkil Poltavskoi oblasti za 1958-1959 n.r., 1959: 59).

In geography lessons, teachers of Lviv region (Verkhnyobilkivska secondary school, Vynnykiv district, Drohobych secondary school № 1) paid great attention to practical classes in geography. "Students of these schools had practical skills in working with maps, geographical accessories. Pupils of V-VII classes of Rozdil seven-year school made many different visual aids, schemes, maps, geographical devices" (Richnyi zvit pro robotu shkil Lvivskoi oblasti za 1958-1959 n.r., 1959: 120).

Teachers of Kherson region involved children in productive work on school educational and research sites, in collective farm production, conducted excursions in nature and agriculture, organized practical work of students in wildlife corners and greenhouses. The teacher of the secondary school № 6 in Kherson in biology lessons "demonstrates all small biological objects to students on the screen with the help of an ordinary microscope" (Richnyi zvit pro robotu shkil Khersonskoi oblasti za 1958-1959 n.r., 1959: 60). Exemplary work on the plots in the secondary school № 4 in Henichesk, secondary schools N-Vorontsovskaya, Tsyurupynska, Holoprystanskaya № 1: program, students conduct systematic observations of plant cultivation (Richnyi zvit pro robotu shkil Khersonskoi oblasti za 1958-1959 n.r., 1959: 60). Schools began to pay more attention to rabbit breeding. "Good porters are created in all schools of Vysokopilsky district." The intensification of teaching methods and the purposefulness of students' work in educational and research areas contributed to the fact that "students have acquired a number of practical skills and abilities to work in agriculture. Thus, students of V-VI grades of secondary schools №№ 3, 17, 6, 7, 27, $30 \mathrm{~m}$. Kherson know the structure of plants well, are able to recognize local plants, grow flowers, field and vegetable crops (Richnyi zvit pro robotu shkil Khersonskoi oblasti za 1958-1959 n.r., 1959: 61). Therefore, to improve the organization of teaching biology in the future, the Methodists saw such steps as strengthening the training facilities and creating classrooms.

This period included "learning skills" and labor nature, the lack of so-called "intellectual skills", but acquired the further development of the formation of "practical skills". M.M. Verzilin, emphasizing the importance of developing skills and abilities during practical work in botany, pointed to the position of the transition from botanical to polytechnic skills (Halytska, 2020: 209). Schools worked to improve research work at school educational and research sites and educational and research economic, student production teams in collective farms (Halytska, 2020: 18). 1959 was characterized by the emergence of differentiated learning, which increased attention to the work of students in educational and research areas.

Order on the implementation of the resolution of the Verkhovna Rada of the Ukrainian SSR, dated August 9, 1962. № 154 "On the implementation of the Law on Strengthening Communications with school life and the further development of the education system," attracted even more attention to the work of students in teaching and research areas; the beginning of the chemical experiment; formation of practical skills and abilities during excursions; organization of research work; the beginning of the introduction of independent work with the textbook; ability to prepare simple experiments (Halytska, 2017: 236). There have been attempts to conduct experiments and observations on their own, practical skills are present, but the emphasis is on the "ability to learn". But in the early 60's of the twentieth century. there is a contradiction in the nature of skills and abilities. Prerequisites are decisions of the XXII Congress of the Central Committee of the CPSU (17.10-31.10.1961). The end of 1961 was marked by a combination of research and practical work with training and production work. In 1962 there was a restructuring of programs, where the emphasis was on the development of polytechnic 
skills. The period from 1963 to 1965 was distinguished by: the emergence of programmed learning; development of research work in chemistry; imitation of best practices; introduction of experimental chemistry lessons; activation of independent work. There was a transition to ten years of study, along with the first attempt to test the level of mental activity of students: comparisons, justifications, conclusions, and this means the emergence of "intellectual skills". By order of 07.10.1963 "On the state of teaching chemistry" focuses on the development of agricultural research. In 1964. the reform of biological education took place. I. Lerner (1965) first drew attention to the research method used by teachers in the classroom, but before that it was encountered only in extracurricular activities (Halytska, 2020: 210).

\section{The period from 1966 to 1972 of the XX century}

1966 was characterized by the transition to a new content of education. Prerequisites were: XXIII Congress of the Central Committee of the CPSU (29.03-08.04.1966), which outlined the direction of public education: education of students' feelings of love for their homeland, preparing them for active employment, and the order of 08.12.1966 "On further improving the work of the school of the USSR", which influenced the formation of a new content of education (education is in the phase of developed socialism).

Mathematics teachers "paid attention to the improvement of methods, laboratory and practical work, the development of spatial imagination and logical thinking" (Zvit pro robotu Ministerstva osvity URSR u 1966-1967 n.r., 1967: 39). Independent work and differentiated learning have significantly improved. Thus, physics teachers of "schools of Kirovograd, Ternopil, Zaporizhia, Kharkiv regions and Kyiv widely use a differentiated approach to students with different theoretical and practical training, offer them various experimental tasks that require serious theoretical knowledge, practical skills and abilities" (Zvit pro robotu Ministerstva osvity URSR u 1966-1967 n.r., 1967: 46).

Attention is drawn to the improvement of skills with modern measuring and computing devices, but still the development of research, design and innovation skills of students takes place in group work. Whereas, practical skills and abilities are developed in lessons in the process of performing practical tasks: while solving problems (computational, qualitative and experimental), performing laboratory and practical work (the ability to use devices, tools, reference books).

In 1966 in the tenth grade a new program in biology is being introduced, which is compiled at the level of modern development of science. More attention is paid to interdisciplinary links, "the use of filmstrips, various illustrations, educational experiment, an integral part of biology are laboratory works" (Zvit pro robotu Ministerstva osvity URSR u 1966-1967 n.r., 1967: 50).

Prerequisites have been created for demonstrations and laboratory work in biology: available biological classrooms; under the guidance of the teacher the work on collecting and registration of handouts is carried out. For example, "secondary schools № 3, 19, 33 in Kharkiv, № 78 in Kyiv, № 18 in Khmelnytsky”, and others. The report of the Ministry of Education for 1966-1967 states that biology students have "some educational and polytechnic skills (handling optical devices, making simple microscopic preparations, recognizing plant and animal organs, systematic groups of plants and animals, sketches, design of herbariums, collections, production of wet preparations). Pupils of rural schools have skills in growing agricultural and ornamental plants, are well acquainted with agricultural research, have skills in pest control of agricultural and ornamental plants" (Zvit pro robotu Ministerstva osvity URSR u 1966-1967 n.r., 1967: 52-53). 
Teachers of geography in the classroom paid attention to the activation of students' thinking, the use of geographical dictations, work with contour maps. "The practice of schools includes the organization of excursions into nature, the production, systematization and qualification processing of the collected material, and its use in lessons" (Zvit pro robotu Ministerstva osvity URSR u 1966-1967 n.r., 1967: 54).

Attention is paid to the formation of skills and abilities provided by the program: measuring work in the field, orientation, phenological observations, use of topographic map, and in senior classes - statistics, various reference books. Attention was paid to the development of independent work with textbooks, graphs, tables, with a map. Geography classrooms have been set up, for example, "Secondary School No. 4 (Vinnytsia), Novobylyansk Secondary School, Novopskovsky District, Luhansk Oblast, provided with maps, equipment, and visual aids materials of students' research work". "Students showed the skills: to navigate and read the map correctly, to work with the scale and coordinate grid, to solve geographical problems, to compare geographical objects, to give economic and geographical characteristics" (Zvit pro robotu Ministerstva osvity URSR u 1966-1967 n.r., 1967: 55-56).

The period 1963-1967 was characterized by the impetus to attempts to classify methods, to the degree of independence, to the work of students in the educational and research area thus a list of skills. The end of 1967 was marked by the rise of knowledge, skills and abilities of independent acquisition of knowledge and the research method began to be used more and more widely. The development of methods for the formation of "generalized skills" has begun. The order of November 19, 1969 "On the state of teaching in new programs and the quality of knowledge" stated that independent work, generalizations, conclusions, research, experiments - acquire the highest level.

In 1969 D. Sergienko distinguishes two types of work: research and practical (under the guidance of a teacher). It is in research work (experiments, observations, experiments) that research skills are formed. Polytechnic education gradually contributed to the emergence of research skills. A. Usova introduces the concept of "generalization of skills", later they began to include intellectual skills (Kartashova, Halytska, 2018: 66). In 1970 the research method is widely used, the problem type of training begins, in which the emphasis is placed on experiments, observations and generalizations.

XXIV Congress of the CPSU (30.03-09.04.1971) and XXIV Congress of the CP of Ukraine, resolutions of the Central Committee of the CPSU and the Council of Ministers of the USSR on completing the transition to general secondary education of youth, improving the content, forms and methods of teaching and communist education of students and student youth.

Already from 1972-1973 academic year, classes VII-X work on new programs. The transition to new programs was completed in 1975. In order to implement the decisions of the Congress, the bodies of public education began to pay more attention to the basics of industrial and agricultural production, working professions, "the formation of labor skills. There are 5,642 student production teams in rural areas, where students are taught to grow high yields and master the elements of agricultural research" (Dopovidni zapysky ta informatsii Ministerstva osvity URSR do Rady Ministriv URSR ta TsK KP Ukrainy z pytan narodnoi osvity (03.01.1973 30.03.1973), 1973: 8). The order of 07.07.1972 "On the completion of the transition to general secondary education", contributed to the diversification of teaching methods and the spread of research approach. Research tasks were considered as a combination of scientific knowledge skills. There was a development of "intellectual skills" that contributed to logical thinking. In the period 1966-1972 there was a complication of educational material, in the programs there were instructions to knowledge, abilities and skills which showed understanding of the 
studied material with which pupils operate at the decision of practical problems. The school became more and more widespread as a general education, labor and polytechnic structure. According to the resolution of the Central Committee of the CPSU and the Council of Ministers of the USSR of June 20,1972. "On the completion of the transition to general secondary education for young people and the further development of secondary school" there was a widespread introduction of the presentation of problem-based learning, attention was paid to the modernization of programs.

\section{Conclusions}

Historical and pedagogical research of students' research skills in mathematics, physics, chemistry, geography, biology, according to the analysis of the regulatory framework and archival sources, allows us to distinguish several periods.

The period of 1959-1965 was characterized by the holding of the XXI, XXII Congresses of the CPSU, the creation of the Law, the transition to a ten-year term of study, which determined the vector of the movement of public education in general and secondary in particular. The quality of the lessons gives us the right to say that during this period the attention of teachers is focused on the main tasks and the improvement of practical skills. Skills tried to be defined for each subject, the means which teachers used, in their opinion, promoted improvement: the organization of laboratory works (physics), chemical experiment (chemistry), work with maps and geographical accessories (geography), communication with other subjects (mathematics), educational and research sites, experiments, observations, nature excursions, practical work in wildlife corners, greenhouses (biology). In the methodology at this time there is an attempt to classify skills. M.M. Verzilin points to the transition of botanical skills to polytechnic skills, which is due to research and practical work in combination with educational and production work, agricultural research.

The period 1966-1972 of the twentieth century. due to the passage of the XXIII and XXIV Congresses of the CPSU, a number of orders that prompted public education to complete the transition to general secondary education, to improve the content, forms and methods of teaching.

Changes began in the formation of skills and abilities. Teachers began to pay more attention to mental operations: analysis, synthesis, comparison. The concept of "intellectual skills" was formed. The quality of the lessons, according to the analysis of archival sources, has increased. Methods during laboratory and practical works are improved, exercises on development of logical thinking are strengthened, independent works and differentiated training (mathematics) promote it. The use of practical and experimental tasks, slides, interdisciplinary links helps to improve practical skills in physics lessons, but attention is drawn to the fact that skills with measuring and computing devices are still improved in the classroom. A wider list of (educational and polytechnic) skills is indicated in biology lessons: collecting collections, handling devices, making micropreparations, plant growing skills, agricultural research. For geography lessons, materials for research work are indicated - map, equipment, visual aids.

Thus, there are enough means to promote the formation of skills, but the question of classification of skills in this period remains open. In the educational and methodological literature there are various concepts of "skills", however, there is no clear transition or mutual transition: "ability to learn" - "polytechnic skills" - "practical skills" - "research skills as polytechnics" "generalization of skills" - "intellectual skills". The prospect of further research is the following historically isolated periods for the development of research skills during the Soviet education. 


\section{References}

Dopovidni zapysky ta informatsii Ministerstva osvity URSR do Rady Ministriv URSR ta TsK KP Ukrainy z pytan narodnoi osvity (03.01.1973-30.03.1973) TsDAVO Ukrainy (Tsentr. Derzh. arkhiv vyshch. orhaniv vlady ta upr. Ukrainy). F. 166. Op. 15. Spr. 8571. Ark. 203. [in Ukrainian] Halytska, N. Ye. (2020). Istorychni aspekty rozvytku doslidnytskoho metodu navchannia pryrodnycho-matematychnykh dystsyplin (kinets 50-kh rr. - seredyna 80-kh rr. XX st.) [Historical aspects of the development of the research method of teaching natural sciences and mathematics (late 50's - mid 80's of the XX century.)] Visnyk Cherkaskoho natsionalnoho universytetu imeni Bohdana Khmelnytskoho. Seriia "Pedahohichni nauky", Cherkasy. [in Ukrainian]

Halytska, N. Ye. (2017). Stanovlennia y rozvytok doslidnytskykh umin uchniv na urokakh pryrodnychykh dystsyplin u zakladakh zahalnoi serednoi osvity (kinets 50-kh - seredyna 90-kh rr. XX st.) [Formation and development of research skills of students in the lessons of natural sciences in general secondary education (late 50's - mid 90's of the XX century.)] Pedahohichnyi almanakh, Kherson. [in Ukrainian]

Halytska, N. Ye. (2020). Samostiina robota uchniv yak zasib formuvannia doslidnytskykh umin na urokakh pryrodnycho-matematychnoho tsyklu (60-ti rr. XX st.) [Independent work of students as a means of forming research skills in the lessons of the natural-mathematical cycle (60s of the XX century)] Colloquium-journal, Warszawa. [in Ukrainian]

Kartashova, I. I., \& Halytska N. Ye. (2018). Tendentsii rozvytku doslidnytskykh umin uchniv u systemi radianskoi shkilnoi osvity (kinets 60-kh-pochatok 80-kh rr. XX st.). [Trends in the development of students' research skills in the system of Soviet school education (late 60's early 80's of the XX century)] Naukovyi chasopys, Kyiv. [in Ukrainian]

Richnyi zvit pro robotu shkil Luhanskoi oblasti za 1958-1959 n.r. TsDAVO Ukrainy (Tsentr. Derzh. arkhiv vyshch. orhaniv vlady ta upr. Ukrainy). F. 166. Op. 15. Spr. 2592. Ark. 85. [in Ukrainian]

Richnyi zvit pro robotu shkil Lvivskoi oblasti za 1958-1959 n.r. TsDAVO Ukrainy (Tsentr. Derzh. arkhiv vyshch. orhaniv vlady ta upr. Ukrainy). F. 166. Op. 15. Spr. 2593. Ark. 203. [in Ukrainian]

Richnyi zvit pro robotu shkil Poltavskoi oblasti za 1958-1959 n.r. TsDAVO Ukrainy (Tsentr. Derzh. arkhiv vyshch. orhaniv vlady ta upr. Ukrainy). F. 166. Op. 15. Spr. 2596. Ark. 138. [in Ukrainian]

Richnyi zvit pro robotu shkil Khersonskoi oblasti za 1958-1959 n.r. TsDAVO Ukrainy (Tsentr. Derzh. arkhiv vyshch. orhaniv vlady ta upr. Ukrainy). F. 166. Op.15. Spr. 2605. Ark.137. [in Ukrainian]

Richnyi zvit pro robotu shkil Chernihivskoi oblasti za $1958-1959$ n.r. TsDAVO Ukrainy (Tsentr. Derzh. arkhiv vyshch. orhaniv vlady ta upr. Ukrainy). F. 166. Op. 15. Spr. 2606. Ark. 90. [in Ukrainian]

Zvit pro robotu Ministerstva osvity URSR u 1966-1967 n.r. TsDAVO Ukrainy (Tsentr. Derzh. arkhiv vyshch. orhaniv vlady ta upr. Ukrainy). F. 166. Op. 15. Spr. 5384. Ark.131. [in Ukrainian] 